\title{
Impact of Management Practices on Water Extractable Organic Carbon and Nitrogen from 12-Year Poultry Litter Amended Soils
}

\author{
Zhongqi He ${ }^{1^{*}}$, Mingchu Zhang ${ }^{2}$, Aiqing Zhao ${ }^{3}$, Heidi M. Waldrip ${ }^{4}$, \\ Paulo H. Pagliari ${ }^{5}$, R. Daren Harmel ${ }^{6}$
}

${ }^{1}$ USDA-ARS, Southern Regional Research Center, New Orleans, USA

${ }^{2}$ Department of Agriculture and Horticulture, University of Alaska Fairbanks, Fairbanks, USA

${ }^{3}$ Editorial Department of the Transactions of the Chinese Society of Agricultural Engineering (TCSAE), Beijing, China

${ }^{4}$ USDA-ARS, Conservation and Production Research Laboratory, Bushland, USA

${ }^{5}$ Department of Soil, Water, and Climate, University of Minnesota, Southwest Research and Outreach Center, Lamberton, USA

${ }^{6}$ USDA-ARS, Center for Agricultural Resources Research, Fort Collins, USA

Email: ${ }^{\star}$ zhongqi.he@ars.usda.gov, *mzhang3@alaska.edu

How to cite this paper: He, Z.Q., Zhang, M.C., Zhao, A.Q., Waldrip, H.M., Pagliari, P.H. and Harmel, R.D. (2017) Impact of Management Practices on Water Extractable Organic Carbon and Nitrogen from 12-Year Poultry Litter Amended Soils. Open Journal of Soil Science, 7, 259-277. https://doi.org/10.4236/ojss.2017.710019

Received: September 6, 2017

Accepted: October 24, 2017

Published: October 27, 2017

Copyright (c) 2017 by authors and Scientific Research Publishing Inc. This work is licensed under the Creative Commons Attribution International License (CC BY 4.0).

http://creativecommons.org/licenses/by/4.0/

\begin{abstract}
Water extractable organic carbon (WEOC) and nitrogen (WEON) are two key parameters of soil water extractable organic matter (WEOM). Proper management of manure application rate in combination with tillage and cropping management could maintain appropriate WEOC and WEON concentrations in soils while decreasing the risk of their runoff from cropland and pastures. The objective of this research was to determine the effect of poultry litter (PL) application on WEOC and WEON in soils under different crops, tillage regimes, and grazing strategies. From 2001 to 2012, PL was applied at multiple rates to cultivated fields in a corn-oat/wheat-hay rotation or to pastures grazed by cattle or ungrazed. Soil samples $(0-15 \mathrm{~cm})$ were analyzed for $\mathrm{KCl}$-extractable mineral $\mathrm{N}$, and WEOC, and WEON contents. In addition, Ultraviolet-visible (UV-vis) and fluorescence spectroscopies were used to characterize WEOC stability. Organic N levels were higher at the high PL application rates. The soil C:N ratio narrowed as the PL application rate increased. However, the soil from pastures which received PL tended to have a wider range of $\mathrm{C}: \mathrm{N}$ ratios than soil from the cultivated fields, despite identical PL application rates. The spectral analyses indicated that WEOC properties were responsive to management and PL application rate; therefore, this parameter may be used as a guide to provide best management strategy for manure application.
\end{abstract}




\section{Keywords}

Biological Index, Humification Index, Poultry Litter, Soil Organic Matter, Specific Absorptivity, UV-Vis Spectroscopy

\section{Introduction}

Animal manure contains essential plant nutrients and functional organic matter components. When used properly, recycling manure as a soil amendment enhances soil fertility, promotes crop growth, and reduces on-farm costs for chemical fertilizer [1]. On the other hand, improper management of manure can result in nutrient runoff from fertilized crop land and pastures, resulting in eutrophication of lakes, rivers and other surface waters [2]. It is crucial for livestock managers and crop producers to obtain a sustainable balance between beneficial manure use/recycling and negative environmental consequences [3]. Understanding long-term effects of manure application on soil water extractable organic matter (WEOM) components in soils is one of the important steps towards achieving this balance.

The majority of poultry (i.e., chickens, turkeys, ducks) reared in the US for meat and eggs are housed in high-capacity, concentrated animal feeding operations (CAFO). All livestock CAFO generate large quantities of manure, which is typically applied to nearby crop or pasturelands as a means of disposal or as local crop fertilizer: the cost of long-distance manure transport is generally not economically viable. In $2015,164 \times 10^{3} \mathrm{Mg}$ of poultry manure was produced in the US [3]. Poultry manure is comprised of feces, uric acid and urine, which are excreted simultaneously. In most instances, manure from poultry operations is in the form of poultry litter (PL), which is manure mixed with bedding material or litter (wood shavings or sawdust) and feathers. Both poultry manure and PL are rich in plant nutrients, including nitrogen $(\mathrm{N})$ and phosphorus $(\mathrm{P})$. With increasing costs of inorganic fertilizers, as well as a push for organic and sustainable agricultural systems, PL is starting to be more frequently transported further from CAFO for use as fertilizer for crops, forage, and pastures [4] [5] [6]. Research [7] [8] [9] showed that inorganic $\mathrm{N}$ and $\mathrm{P}$ can run off from both cropland and pasture after PL application. While numerous studies have focused on runoff $\mathrm{N}$ and $\mathrm{P}$ from manure, less attention has been paid to how manure impacts WEOC and WEON in soil which are two key WEOM components [10] [11] [12] [13] [14].

Soil organic matter (SOM) plays an important role in soil quality and nutrient cycling [15]. Soil WEOM is an active, mobile and complex fraction of SOM and is sensitive to land use and management practices [16] [17] [18]. In addition, soil WEOM can contribute significant amounts of dissolved organic $\mathrm{C}$ and $\mathrm{N}$ to surface waters [19] [20]. In recent years, ultraviolet-visible (UV-vis) and fluorescence spectroscopies have been used to characterize WEOM in soil, manure and other environmental samples [11] [21] [22] [23]. These two spectroscopic me- 
thods for WEOM studies are advantageous because of high sensitivity, relatively simple ease of operation, and the broader instrument availability, compared to some other more sophistic spectroscopic technologies. Waldrip et al. [24] used UV-vis analysis to study WEOM in beef feed yard manure samples, where large differences in molecular weight, lignin content, and proportion of humified organic matter between manures from different sources were found. Mouloubou et al. [25] used spectroscopic techniques to investigate changes of WEOM and pyrophosphate-extracted organic matter (OM) after annual compost amendment. In this study, rapid quantitative and qualitative changes were noted in both WEOM and pyrophosphate-extractable OM after compost application, primarily during the first 3 months after application. Zeng et al. [26] used fluorescence excitation-emission matrix (EEM) spectroscopy, coupled with parallel factor analysis (PARAFAC), and revealed that WEOM in swine wastewater after anaerobic digestion was primarily comprised of tryptophan-like, humic acid-like, and fulvic acid-like substances.

In 2000, a comprehensive, long-term watershed-scale (1.2 to 8.4 ha) study was initiated at the USDA-ARS research site at the Grassland Soil and Water Research Laboratory near Riesel, TX, USA $\left(31.47^{\circ} \mathrm{N}, 96.93^{\circ} \mathrm{W}\right)$ to evaluate the economic, agronomic, and environmental effects of PL application on a calcareous Texas Houston Black clay soil ( 17\% calcium carbonate $\left.\left(\mathrm{CaCO}_{3}\right)\right)$ [7] [9] [27]. Haney et al. [28] compared soils from the Riesel study to soils collected from agricultural fields in Idaho, Georgia, Maine, Mississippi Oklahoma, Texas, and Wyoming to understand the relationship between soil organic C:N and WEOC:WEON. They concluded that the WEOC:WEON ratio was a more sensitive measurement than total $\mathrm{C}: \mathrm{N}$ because of the direct influence of soluble $\mathrm{C}$ and $\mathrm{N}$ on microbial metabolism. Thus, to increase the knowledge of forms and availability of soluble $\mathrm{C}$ and $\mathrm{N}$ in PL-amended soils, we characterized WEOC with UV-vis spectroscopy and fluorescence EEM spectroscopy. The objectives of this research were to determine the 1) impact of rate of PL application on soil WEOC and WEON concentrations; 2) effects of management practices on soil WEOC and WEON concentrations; and 3) UV-Vis and fluorescence spectral features of soil WEOM as affected by PL application and management practices.

\section{Materials and Methods}

\subsection{Management Practices and Sample Collection}

Poultry litter has been applied annually to small watersheds from 2000 to 2016 at the USDA-ARS Grassland, Soil and Water Research Laboratory near Riesel, Texas, USA $\left(31.47^{\circ} \mathrm{N}, 96.93^{\circ} \mathrm{W}\right)$. Ten fields (watersheds) were the experimental units, each with a land-use (six cultivated and four pasture) and litter rate (0.0 13.4 Mg.ha ${ }^{-1}$ ) component. Detailed information for the fields can be found in publications by Harmel et al. [7] [27]. A brief summary is listed in Table 1. The $\mathrm{PL}$ on average contained $30.3 \% \mathrm{C}, 2.61 \% \mathrm{~N}$, and $2.01 \% \mathrm{P}$. Application rates for $\mathrm{PL}$ were determined a priori and then randomly assigned to specific watersheds. 
Table 1. Yearly average litter/fertilizer application and management for each treatment from 2000 to 2012 .

\begin{tabular}{|c|c|c|c|c|}
\hline Field & $\begin{array}{l}\text { Litter rate } \\
\left(\mathrm{Mg}^{-h^{-1}}\right)^{-1}\end{array}$ & $\begin{array}{c}\text { Inorganic N } \\
\left(\mathrm{kg} \cdot \mathrm{ha}^{-1}\right)\end{array}$ & $\begin{array}{l}\text { Inorganic } \mathrm{P}_{2} \mathrm{O}_{5} \\
\left(\mathrm{~kg} \cdot \mathrm{ha}^{-1}\right)\end{array}$ & Management \\
\hline Y6 & 0 & 139 & 37 & $\begin{array}{l}\text { Reduced tillage, corn-wheat/oats-hay, } \\
\text { traditional high rate inorganic fertilizer. }\end{array}$ \\
\hline Y13 & 4.5 & 56 & 0 & $\begin{array}{l}\text { Reduced tillage, corn-wheat/oats-hay, } \\
\text { poultry litter plus supplemental } \\
\text { N if needed. }\end{array}$ \\
\hline Y10 & 6.7 & 49 & 0 & $\begin{array}{l}\text { Reduced tillage, corn-wheat/oats-hay, } \\
\text { poultry litter plus supplemental } \\
\text { N if needed. }\end{array}$ \\
\hline W12 & 9.0 & 47 & 0 & $\begin{array}{l}\text { Reduced tillage, corn-wheat/oats-hay, } \\
\text { poultry litter plus supplemental } \\
\text { N if needed. }\end{array}$ \\
\hline W13 & 11.2 & 19 & 0 & $\begin{array}{l}\text { Reduced tillage, corn-wheat/oats-hay, } \\
\text { poultry litter plus supplemental } \\
\text { N if needed. }\end{array}$ \\
\hline Y8 & 13.4 & 0 & 0 & $\begin{array}{l}\text { Reduced tillage, corn-wheat/oats-hay, } \\
\text { poultry litter. }\end{array}$ \\
\hline SW12 & 0 & 0 & 0 & $\begin{array}{l}\text { Native pasture, no grazing, } \\
\text { single annual hay harvest. }\end{array}$ \\
\hline SW17 & $6.7^{1}$ & 0 & 0 & $\begin{array}{l}\text { Pasture, grazed until 2010, poultry litter } \\
\text { compost applied 2011-2012 at } \\
6.7 \mathrm{Mg} \cdot \mathrm{ha}^{-1} \text {. }\end{array}$ \\
\hline Y14 & $6.7-13.4^{2}$ & 0 & 0 & $\begin{array}{l}\text { Hay harvested each year, poultry litter } \\
\text { applied } 2001-2007 \text { at } 13.4 \mathrm{Mg} \cdot \mathrm{ha}^{-1} \text { and } \\
\text { 2011-2012 at } 6.7 \mathrm{Mg} \cdot \mathrm{ha}^{-1} \text {. }\end{array}$ \\
\hline W10 & $6.7^{3}$ & 0 & 0 & $\begin{array}{l}\text { Hay harvested each year until } 2010 \text {, } \\
\text { grazed from 2010-2012, poultry litter } \\
\text { applied 2001-2007 at } 6.7 \mathrm{Mg} \cdot \mathrm{ha}^{-1} \text {. }\end{array}$ \\
\hline
\end{tabular}

${ }^{1}$ Litter applied only in 2011, 2012 at 6.7 Mg.ha ${ }^{-1} .{ }^{2}$ Litter applied in 2001-2007 at 13.4 Mg.ha ${ }^{-1}$ and 2011-2012 at $6.7 \mathrm{Mg} \cdot \mathrm{ha}^{-1} \cdot{ }^{3}$ Litter applied from 2001-2007 at $6.7 \mathrm{Mg} \cdot \mathrm{ha}^{-1}$.

PL was applied using "real world" practices, where desired rate was met according to truck speed, gear, and rear gate settings. The PL, a mixture of manure and bedding (either wood shavings or rice hulls), was obtained from the cleanout (either complete cleanout for multiple flocks or "cake out" from a single flock) of turkey and broiler houses near the study site. Litter samples were collected annually prior to soil application.

Soil at the site is dominated by a Houston Black clay soil (typical Vertisol). Soil samples were taken annually during winter to a depth of $15 \mathrm{~cm}$. A random sampling strategy was employed that was stratified to ensure that samples were collected from the top, middle, and lower portions of each watershed at a frequency of at least one core per 0.4 ha. The soil cores were combined to create one composite sample per watershed. This composite field sampling enables a substantial saving in total cost in many soil investigations, and could be applied 
under certain conditions [29]. The strategy has been used in estimations of PL amendment effects on average changes in the soil $\mathrm{P}$ chemical distribution, without increasing the time and cost of analyses, of the soil samples used for this study [9].

\subsection{WEOM Extraction and Analysis}

The water content of the stored soil samples was determined at $105^{\circ} \mathrm{C}$ for calculation of nutrients and $\mathrm{C}$ on a soil mass basis. Soils were extracted with deionized water at a soil/solution ratio of 1:10. The mixtures were shaken for $30 \mathrm{~min}$ on an Eberbach reciprocal shaker (Eberbach Corporation, Ann Arbor, MI), centrifuged at $900 \times \mathrm{g}$ for $30 \mathrm{~min}$ at room temperature $\left(22^{\circ} \mathrm{C}\right)$, and then filtered through a $0.45-\mu \mathrm{m}$ GN-6 Metricel MCE Membrane Disc filter (Pall Industries,). Water extractable organic C (WEOC) and total N (WETN) in the extracts were determined using Shimadzu TOC-V Organic Carbon and Total Nitrogen Analyzer (Shimadzu Scientific Instruments, Inc., Columbia, MD) according to the method of Haney et al. [28]. Preliminary studies indicated that insignificant concentrations of inorganic $\mathrm{C}\left(\mathrm{CaCO}_{3}\right)$ were present in the WEOM from the experimental soils. Thus, for the current study, total $\mathrm{C}$ concentration of WEOM measured with the Shimadzu instrument was assumed to be representative of WEOC. Concentrations of WEON in the WEOM were derived by subtracting mineral $\mathrm{N}$ (i.e., ammonium/ammonia and nitrate/nitrite) from the total $\mathrm{N}$ measured in the WEOM according to Zhang et al. [10].

\subsection{Spectroscopic Analysis}

The WEOM samples were diluted for UV-vis and fluorescence spectroscopic measurements as described previously [20] [30]. For UV-vis spectroscopy, the absorbance of the solution from 200 to $700 \mathrm{~nm}$ was measured using a $10-\mathrm{mm}$ (width) quartz cuvette and a UV-VIS-NIR spectrometer (Shimadzu Scientific Instruments Inc., Columbia, $\mathrm{MD})$. Absorbance $\left(\mathrm{m}^{-1}\right)$ was expressed as the ratio between optical density and optical length $(0.01 \mathrm{~m})$. The ultraviolet (UV) absorptivity at 254 or $280 \mathrm{~nm}\left(\mathrm{SUVA}_{254}\right.$ or $\left.\mathrm{SUVA}_{280}, 1 \mathrm{mg} \mathrm{C}^{-1} \mathrm{~m}^{-1}\right)$ was calculated as $\left(\mathrm{Abs}_{254} / \mathrm{WEOC}\right) \times 100$ or $\left(\mathrm{Abs}_{280} / \mathrm{WEOC}\right) \times 100$. The ratios of E2/E3 $\left(\mathrm{A}_{250} / \mathrm{A}_{365}\right)$ and $\mathrm{E} 4 / \mathrm{E} 6\left(\mathrm{~A}_{400} / \mathrm{A}_{600}\right.$ or $\left.\mathrm{A}_{465} / \mathrm{A}_{665}\right)$ were calculated to evaluate the effect of the PL application soil WEOM properties.

Fluorescence EEM spectra were obtained using a Fluomax-4 fluorescence spectroscopy (Jobin Yvon Horiba, Edison, NY) equipped with a 150-W ozone free xenon lamp as the excitation source. Before fluorescence measurement, the WEOM samples were diluted by adding Deionized (DI) water so that the UV absorbance of the extracts at $240 \mathrm{~nm}$ reached around 0.1, in order to avoid inner filter effects. The diluted samples were then used for acquiring fluorescence EEM spectra with excitation wavelengths of $240-400 \mathrm{~nm}$ and emission wavelengths of $300-500 \mathrm{~nm}$. The increments for excitation and emission wavelengths were 3 $\mathrm{nm}$. The band widths were $5 \mathrm{~nm}$ for both excitation and emission slits, and the 
integration time was $0.1 \mathrm{~s}$. The original EEM spectra were then corrected for instrument bias and Rayleigh scatter lines using the program created by the manufacturer. The "final" EEM spectra of the extracts were obtained by first subtracting the controls (average of three replicates) to remove Raman scatter effects, and then normalized for the area representing the Raman peak for DI water at an excitation wavelength $350 \mathrm{~nm}$. In areas where the emission wavelength was smaller than excitation wavelength, fluorescence is physically impossible; thus, a value of zero was used to replace the fluorescence intensity of these areas. The PARAFAC analysis was conducted using the PLS Toolbox 5.0 (Eigenvector Research, Manson, WA) in MATLAB (V7 release 14, Mathworks, Natic, MA) environment. The number of components in the EEM data set was evaluated by core consistency with a diagnostic score close to $100 \%$. Various fluorescence parameters were calculated from the spectral data per the definition of each parameter [21] [23]. Specifically, the fluorescence index (FIX) was calculated as the ratio of emission intensity at $\mathrm{Em} 450 \mathrm{~nm}$ to that at Em $500 \mathrm{~nm}$ for an excitation wavelength of $370 \mathrm{~nm}$. Polyphenol-like or protein-like fluorescence (PLF) was the fluorescence intensity at excitation wavelength of $275 \mathrm{~nm}$ and emission wavelength of $350 \mathrm{~nm}$. The Biological index (BIX) was calculated as the ratio of fluorescence intensity of emission at $380 \mathrm{~nm}$ over $430 \mathrm{~nm}$ with the excitation wavelength at $310 \mathrm{~nm}$. Fluorescence intensities of WEOM at Ex $254 \mathrm{~nm}$ and Em $300-480 \mathrm{~nm}$ were used to calculate their humification (HIX) values using the equation HIX $=\Sigma \mathrm{I} 435 \rightarrow 480 / \Sigma \mathrm{I} 300 \rightarrow 345$, in which $\Sigma \mathrm{I} 300 \rightarrow 345$ was the sum of fluorescence intensity at Em 300 to $345 \mathrm{~nm}$, and $\Sigma \mathrm{I} 435 \rightarrow 480$ was the sum of fluorescence intensity at Em 435 to $480 \mathrm{~nm}$.

\subsection{Data Analysis}

Analysis of variance (ANOVA) was conducted to determine the effects of PL application and management practices on mineral $\mathrm{N}$ as $\mathrm{NO}_{3}-\mathrm{N}$ and $\mathrm{NH}_{4}-\mathrm{N}$ and on WEOM properties including WEOC and WEON along with properties measured with UV-vis and fluorescence spectroscopies. Analyses were conducted with a $P$ value $\leq 0.05$ using SYSTAT ${ }^{\circ}$ Version 13.0 (San Jose, CA).

\section{Results and Discussion}

\subsection{WEOC and WEON Concentrations in Soil after Long-Term PL Application}

The soil WEOC and WEON concentrations varied from year to year, indicating dynamics of labile soil C (Figure 1) and N (Figure 2) and the spatial variability of these properties. The variation reflects the instability (in other words, lability) of the soil WEOM. This effect was previously found in soils that received manure amendment [31]. In the current study, PL application increased the WEOC levels in the five cultivated soils (Y13, Y10, W12, W13, Y8), compared to the no PL control (Y6) in the corresponding year. However, PL application did not impact WEOC level in the pasture soils (SW17, W10, and Y14), compared to 


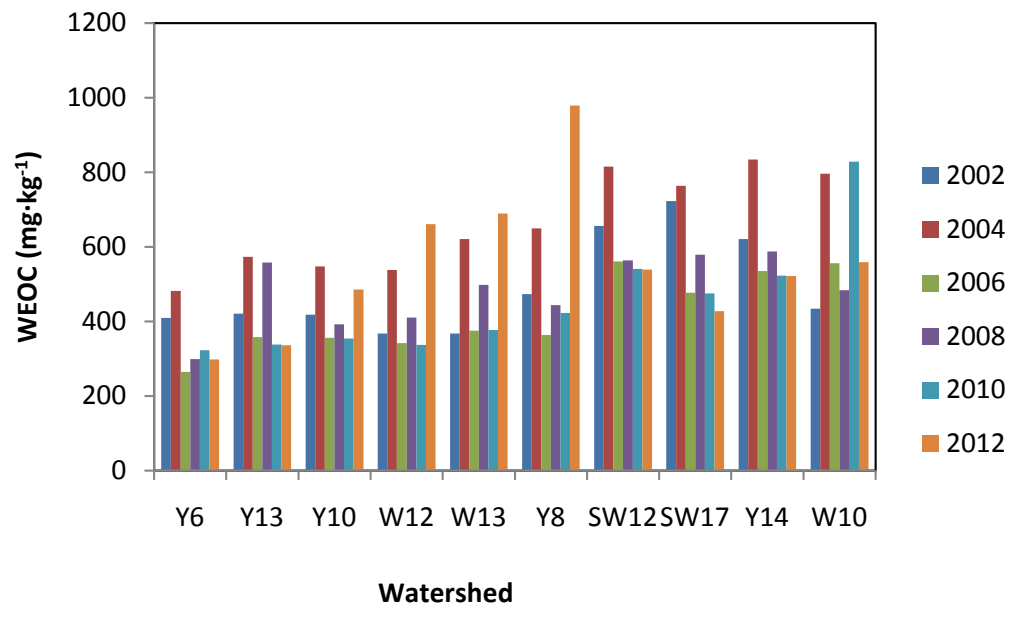

Figure 1. Water extractable organic carbon (WEOC) changes over time from different treatments. Y6: inorganic N, Y13, Y10, W12, W13, and Y8: PL application rate ranged from 4.5 to $13.4 \mathrm{Mg} \cdot \mathrm{ha}^{-1}$, SW12: native grassland, SW17: grazed pasture, Y14: hay field, W10: grazed pasture.

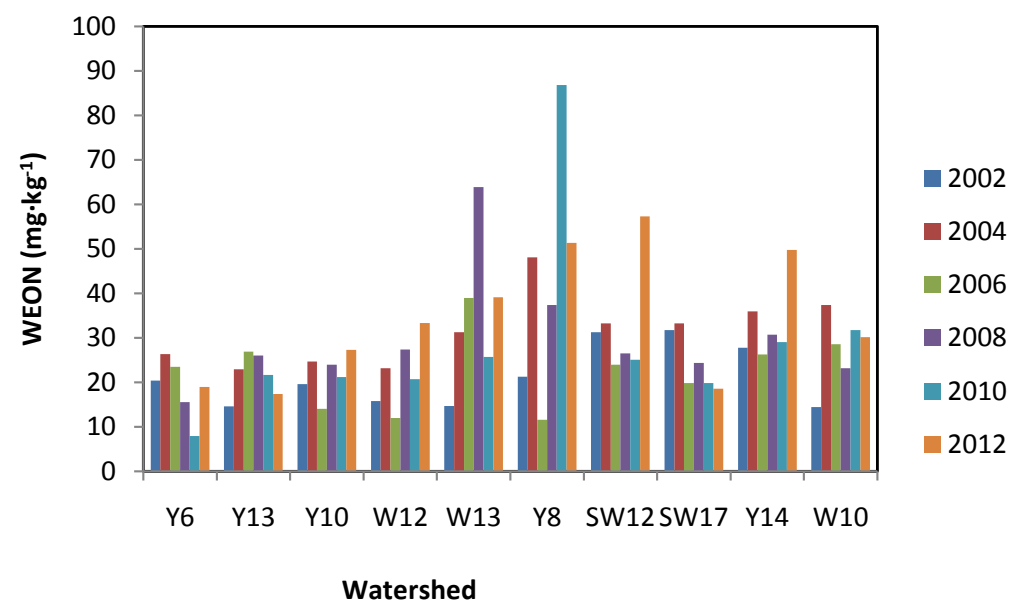

Figure 2. Water extractable orgaic nitrogen (WEON) changes over time from different treatments. Y6: inorganic N, Y13, Y10, W12, W13, and Y8: PL application rate ranged from 4.5 to $13.4 \mathrm{Mg} \cdot \mathrm{ha}^{-1}$, SW12: native grassland, SW17: grazed pasture, Y14: hay field, W10: grazed pasture.

unamended control (SW12). This observation of no effect could be attributed to the inherent high WEOC levels in the no-PL-application pasture soil, compared to those corresponding data in the no-PL application cultivated soils. The add-on effect of WEOC derived from PL would be relatively less in these pasture soils. In contrast to PL effects on WEOC, PL application did not have a clear effect on soil WEON levels. Soil WEON is directly related to the amount of potential mineralizable soil N [4] [12]; therefore, high soil WEON can contribute soil $\mathrm{NO}_{3}-\mathrm{N}$. Even with this variation over years, on average, the WEOC and WEON were higher in the pasture fields as compared to the cultivated fields. It was clear that cultivation likely enhanced the decomposition of soil WEOM. Despite year-to-year variation, the accumulation of WEON was observed when PL ap- 
plication rate exceeded $9 \mathrm{Mg} \cdot \mathrm{ha}^{-1}$. In addition, continuous application $<9$ $\mathrm{Mg} \cdot \mathrm{ha}^{-1}$ could also result in increase of WEON (Figure 2).

For further analysis of these data, average and standard deviation were calculated using sampling years as replicates to reflect the variations of the relevant $\mathrm{C}$ and $\mathrm{N}$ parameters over sampling impacted by $\mathrm{PL}$ application rates. In the cultivated fields, soil $\mathrm{NO}_{3}-\mathrm{N}$ concentrations increased with $\mathrm{PL}$ application rate (Table 2). No statistical difference was found in soil $\mathrm{NH}_{4}-\mathrm{N}$ concentrations among treatments. The WEOC content of the cropped watershed that received only chemical fertilizer (Y6) was lower than the fields that received PL; however, no statistical differences $(p>0.05)$ were found in WEOC from watershed that received $\mathrm{PL}$ at different rates. In contrast, the soil WEON did not vary signifi-

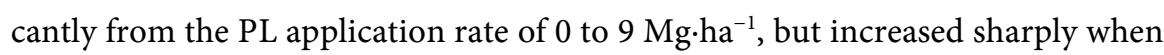
the PL application rate increased from $9 \mathrm{Mg} \cdot \mathrm{ha}^{-1}$ to $11.2 \mathrm{Mg} \cdot \mathrm{ha}^{-1}$. The WEON concentration was nearly doubled in Y8 (13.4 ${\left.\mathrm{Mg} \cdot \mathrm{ha}^{-1}\right)}$ in comparison with Y6 (0 Mg.ha ${ }^{-1}$ ), Y13 (4.5 Mg.ha $\left.{ }^{-1}\right)$, Y10 (6.7 Mg.ha ${ }^{-1}$ ) and W12 (9.0 Mg.ha $\left.{ }^{-1}\right)$. The $\mathrm{C}: \mathrm{N}$ ratios for WEOM, on the other hand, were narrow in watersheds that received the high PL rate, as compared to low PL rate treatments.

All soil samples were taken in the winter; thus, high $\mathrm{NO}_{3}-\mathrm{N}$ concentrations could be the result of mineralization of soluble organic $\mathrm{N}$ from the PL after the end of the growing season. Thus, this could represent a source of residual $\mathrm{N}$ for next-season planting unless leached prior to planting. In the previous study from the same research site, Harmel et al. [7] reported lower $\mathrm{NO}_{3}-\mathrm{N}$ runoff from the

Table 2. Average mineral N, soil water soluble organic $\mathrm{C}$ and $\mathrm{N}$, and UV-Vis spectral parameters of WEOM fractions from soil samples taken from each treatment in two-year interval from 2000 to 2012, the numbers are annual average (standard deviation) values.

\begin{tabular}{|c|c|c|c|c|c|c|c|c|c|c|}
\hline & $\mathrm{NH}_{4}-\mathrm{N}$ & $\mathrm{NO}_{3}-\mathrm{N}$ & WEOC & WEON & & & & & & \\
\hline Field & \multicolumn{4}{|c|}{ 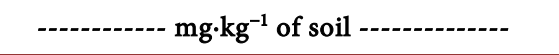 } & $\mathrm{C}: \mathrm{N}$ & SUVA $_{254}{ }^{1}$ & SUVA $_{280}{ }^{2}$ & $\mathrm{E} 2 / \mathrm{E}^{3}{ }^{3}$ & $\mathrm{E} 4 / \mathrm{E} 6-1^{4}$ & $\mathrm{E} 4 / \mathrm{E} 6-2^{5}$ \\
\hline Y6 & $7.5(2.8)$ & $9.8(6.6)$ & $346(83)$ & $18.9(6.5)$ & 21 & $0.20(0.04)$ & $0.16(0.03)$ & $3.43(0.23)$ & $2.22(0.24)$ & $1.64(0.14)$ \\
\hline Y13 & $7.7(3.8)$ & $11.8(9.1)$ & 431 (109) & $21.6(4.8)$ & 21 & $0.19(0.02)$ & $0.15(0.01)$ & $3.48(0.16)$ & $2.44(0.11)$ & $1.74(0.08)$ \\
\hline Y10 & $6.8(3.0)$ & $19.0(10.9)$ & $426(77)$ & $21.8(4.7)$ & 20 & $0.21(0.01)$ & $0.17(0.01)$ & $3.53(0.08)$ & $2.62(0.25)$ & $1.82(0.10)$ \\
\hline W12 & $6.7(2.6)$ & $19.5(13.8)$ & $443(130)$ & $22.1(17.8)$ & 21 & $0.17(0.02)$ & $0.14(0.02)$ & $3.51(0.10)$ & $2.52(0.19)$ & $1.69(0.09)$ \\
\hline W13 & $8.3(3.1)$ & $22.1(17.9)$ & $488(140)$ & $35.6(16.6)$ & 16 & $0.18(0.03)$ & $0.14(0.02)$ & $3.48(0.11)$ & $2.70(0.43)$ & $1.80(0.20)$ \\
\hline Y8 & $9.0(3.5)$ & $22.2(13.4)$ & 555 (229) & $42.8(26.5)$ & 17 & $0.22(0.03)$ & $0.18(0.02)$ & $3.45(0.09)$ & $2.77(0.32)$ & $1.92(0.16)$ \\
\hline SW12 & $7.3(3.0)$ & $5.4(3.2)$ & $613(108)$ & $32.9(12.5)$ & 20 & $0.17(0.05)$ & $0.13(0.04)$ & $3.57(0.23)$ & $2.47(0.25)$ & $1.81(0.14)$ \\
\hline SW17 & $7.3(3.5)$ & $6.1(5.5)$ & $574(141)$ & $24.6(6.5)$ & 23 & $0.14(0.03)$ & $0.11(0.02)$ & $3.15(0.24)$ & $2.17(0.17)$ & $1.67(0.15)$ \\
\hline Y14 & $10.0(7.1)$ & $11.1(7.4)$ & $604(120)$ & $33.3(8.8)$ & 19 & $0.20(0.04)$ & $0.16(0.04)$ & $3.37(0.21)$ & $2.60(0.28)$ & $1.90(0.14)$ \\
\hline W10 & $7.4(3.7)$ & $8.1(5.9)$ & $610(164)$ & $27.6(7.9)$ & 23 & $0.15(0.02)$ & $0.12(0.01)$ & $3.45(0.21)$ & $2.50(0.23)$ & $1.79(0.08)$ \\
\hline Prob $^{6}$ & 0.75 & 0.0095 & 0.0004 & 0.0130 & & 0.0005 & 0.0004 & 0.018 & 0.0001 & 0.0016 \\
\hline $\operatorname{LSD}(0.05)^{7}$ & NA & 5.4 & 61 & 6.6 & & 0.017 & 0.014 & 0.10 & 0.07 & 0.12 \\
\hline
\end{tabular}

${ }^{1} \mathrm{SUVA}_{254}$ : Specific absorptivity at wavelength $254 \mathrm{~nm} .{ }^{2} \mathrm{SUVA}_{280}$ : Specific absorptivity at wavelength $280 \mathrm{~nm}$. ${ }^{3} \mathrm{E} 2 / \mathrm{E} 3$ : ratio of UV-Vis absorbance of wavelength of $250 \mathrm{~nm}$ over $365 \mathrm{~nm} .{ }^{4} \mathrm{E} 4 / \mathrm{E} 6-1$ : ratio of UV-Vis absorbance of wavelength of $400 \mathrm{~nm}$ over 600 nm [42] [52]. ${ }^{5} \mathrm{E} 4 / \mathrm{E} 6-2$ : ratio of UV-Vis absorbance of wavelength of $465 \mathrm{~nm}$ over $665 \mathrm{~nm}$ [53]. ${ }^{6}$ ANOVA was conducted using samples from different years as replicates. ${ }^{7}$ LSD (0.05): Least Significant Difference at $5 \%$ probability. 
PL treated soils compared to the field with inorganic $\mathrm{N}$ application. The authors attributed this to the slow release characteristics of the organic $\mathrm{N}$ source. The present study substantiated this hypothesis as no increase was observed in soil $\mathrm{NO}_{3}-\mathrm{N}$ while WEON increased as litter rate increased from $9 \mathrm{Mg} \cdot \mathrm{ha}^{-1}$ to 13.4

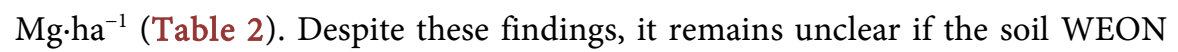
contributes to total $\mathrm{N}$ in runoff water. There is a need for further research in this area. Also, the results demonstrated a relationship between rate of PL application and accumulation of WEON in soil. The $9.0 \mathrm{Mg} \cdot \mathrm{ha}^{-1} \mathrm{PL}$ application rate was the upper threshold, beyond which elevated WEON accumulated in soil. In the pasture field, grazing did not change soil $\mathrm{C}$ and $\mathrm{N}$ properties, with the exception of soil WEON.

\subsection{UV-Vis Spectral Features and Parameters of Soil WEOM after Long-Term PL Application}

The UV-vis spectra of the representative WEOM samples from cultivated (Figure 3) and pasture (Figure 4) soils were quite similar. In general, the spectral features were quite similar or even identical in shape between the two land-use types. In other words, the general feature of these spectra is a monotonically decreasing curve with increasing wavelength. This observation was consistent with the WEOM characteristics in various manure [24] [32], plant [23] [33] [34] and soil samples [32] [36]. Due to the relatively simple features of UV-vis spectra, more specific UV-vis parameters were calculated to evaluate quantitatively the impact of PL application on the soil WEOM properties (Table 2).

$\mathrm{SUVA}_{254}$ and $\mathrm{SUVA}_{280}$ are two parameters used to assess the aromaticity, hydrophobic content, and molecular size of WEOM [12] [13]. As observed previously [31], the trends of changes in the two sets of data were similar, even

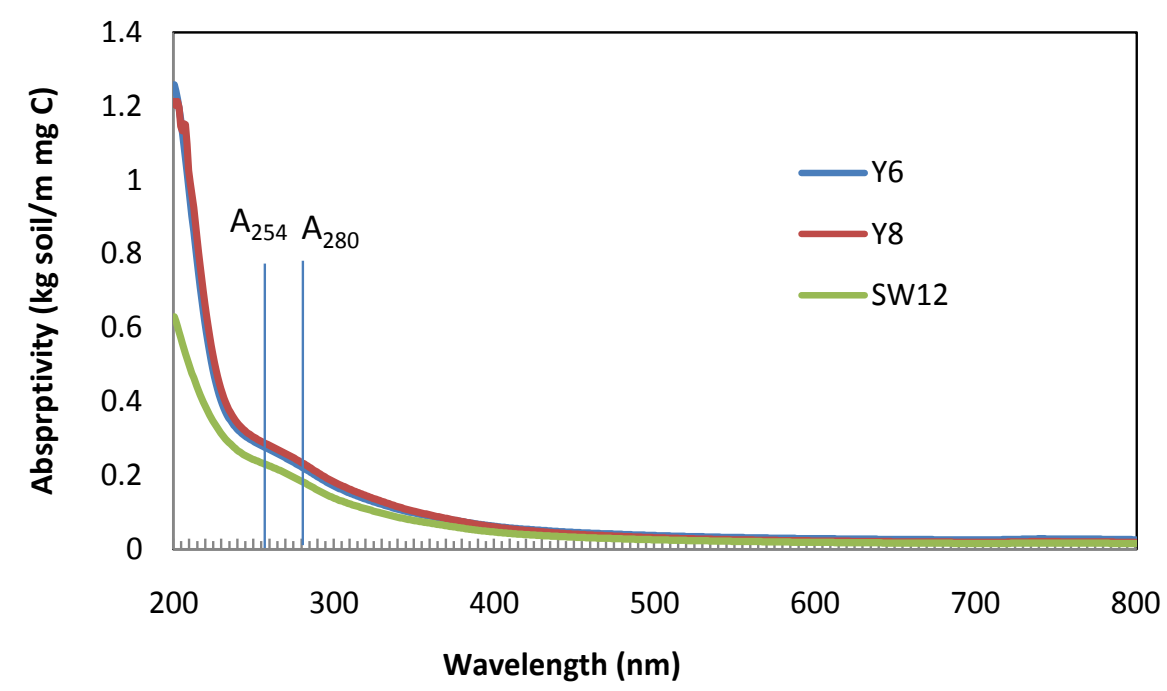

Figure 3. Average UV-Vis absorptivity of soil water extractable organic matter (WEOM) from wavelengths of 200 to $800 \mathrm{~nm}$ among inorganic fertilizer (Y6), high PL application rate (Y8) and native grassland (W12). Vertical lines indicate the specific absorptivity of $\mathrm{A}_{254}$ and $\mathrm{A}_{280}$. 


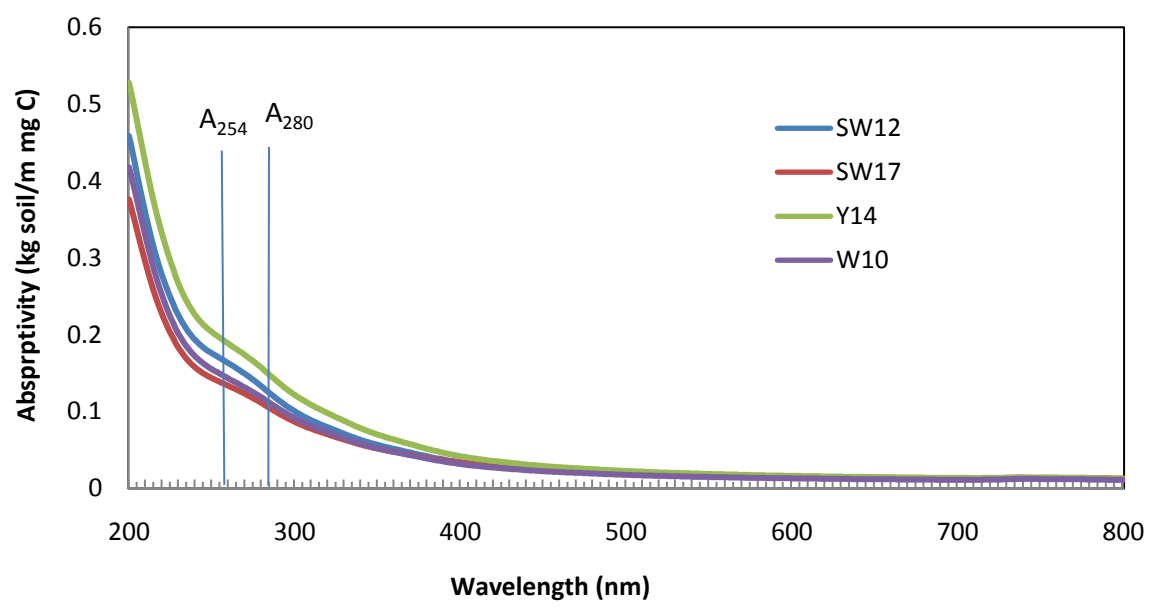

Figure 4. Average UV-Vis absorptivity of soil water extractable organic matter (WEOM) for wavelengths of 200 to $800 \mathrm{~nm}$ among native grassland (SW12), grazed grassland (SW17), hay field (Y14), and PL application rate ranged from 3.6 to $10.8 \mathrm{Mg} \cdot \mathrm{ha}^{-1}$, SW12: native grassland, SW17: grazed pasture, Y14: hay field, W10: grazed pasture (W10). Vertical lines indicate the specific absorptivity of $\mathrm{A}_{254}$ and $\mathrm{A}_{280}$.

though the values of $\mathrm{SUVA}_{254}$ were greater than those of $\mathrm{SUVA}_{280}$ in the corresponding samples. However, it should be noted that the average $\mathrm{SUVA}_{254}$ and $\mathrm{SUVA}_{280}$ values obtained for these Texas black clay soils were approximately 0.2 $\mathrm{m}^{-1} \cdot \mathrm{mg}^{-1} \mathrm{C} \mathrm{L}$, values that were much lower than the approximate average SUVA values of $2.0 \mathrm{~m}^{-1} \cdot \mathrm{mg}^{-1} \mathrm{C} \mathrm{L}$ for a Maine Caribou sandy loam with rotated potato cropping systems [31] and $2.2-4.3 \mathrm{~m}^{-1} \cdot \mathrm{mg}^{-1} \mathrm{C} \mathrm{L}$ in an Alabama pasture with Hartselle soil and PL application [11]. The $<2.0 \mathrm{~m}^{-1} \cdot \mathrm{mg}^{-1} \mathrm{C} \mathrm{L} \mathrm{SUVA}{ }_{254}$ value in this study was an indication of the low aromaticity of these Texas soil samples, as proposed in earlier studies [35] [36]. In the cultivated fields, the spectral parameters of the soil WEOM from high PL application rate was still quite close to the soil that received only inorganic fertilizer application, indicating that cultivation might be a major variable that controls the spectral property of soil WEOM. Comparison of the cultivated field with high PL rate (Y8) and inorganic fertilizer (Y6) to native grassland (SW12) showed that both cultivated fields had higher $\mathrm{SUVA}_{254}$ and $\mathrm{SUVA}_{280}$ than native grassland, suggesting their high aromaticity and low decomposability. Even the concentrations of soil WEOC and WEON were higher in Y8 (high PL application rate) than that in Y6 (inorganic fertilizer). The finding of larger amounts of aromatic-type WEOM in both Y8 and Y6 indicated that fertilizer form or rate did not impact WEOM spectral features, but this property was more influenced by cultivation. He et al. [31] reported that crop rotation increased, but irrigation decreased, the values of both SUVA parameters. Thus, the SUVA values were probably effected mainly by the inherent aromaticity of indigenous plant-derived structure [31] [37].

The spectral ratio of E2/E3 tended to be higher for PL treated soils as compared to the soil only received inorganic fertilizers (Table 2). The E4/E6 ratios were higher for soils with PL application as compared to the soil with inorganic fertilizers. The soil in grazed field (SW17) had a lower ratio of E2/E3, indicating 
that soil WEOM from grazed pasture is well decomposed and condensed. High stability of WEOM in grazed pasture was also reflected by the lower ratios of E4/E6 from these soils. Higher E2/E3 and E4/E6 ratios indicate existence of decomposable organic compounds [11]. Hunt et al. [38] reported the E2/E3 ratio of the WEOM fractions of fresh poultry manure as 64.0 and 6.7 for its hydrophilic and hydrophobic fractions, respectively. After decomposition, the E2/E3 ratios of the two fractions changed to 6.0 and 4.7, respectively, indicating the dominance and rapid degradation of the hydrophilic compounds in poultry manure. E4/E6 ratios have been measured in three wavelength ranges. In addition of the two measurements at the wavelength of $400 \mathrm{~nm}$ over $600 \mathrm{~nm}$, and 465 $\mathrm{nm}$ over $465 \mathrm{~nm}$ reported in Table 2, it is also measured $472 \mathrm{~nm}$ over $664 \mathrm{~nm}$ [24] [39]. Selection of higher wavelengths seemed to result in lower E4/E6 values (Table 2); thus, it is important to note the specific wavelengths used for sophisticated comparison of the quantitative E4/E6 data in literature. He et al. [31] reported no statistically significant $(p>0.05)$ correlation coefficients between E4/E6 and SUVA 254 or SUVA 280 in the WEOM fraction of their Maine soil samples, suggesting that E4/E6 is an independent parameter. On the other hand, Osborne et al. [40] and Silveira et al. [41] reported unsuccessful efforts at predicting and characterizing plant little-related WEOM with E4/E6 ratio measured at $465 \mathrm{~nm}$ over $665 \mathrm{~nm}$. In this study, E4/E6 values could not be used to assess the impact of specific treatments. However, a general conclusion can be made from the E4/E56 data: PL application increased decomposable hydrophilic OM fractions and that grazing enhanced cycling soluble OM in the soil.

\subsection{Fluorescence Spectroscopic Features}

The fluorescence EEM spectra of four representative samples are presented in Figure 5. The spectra of Y6 and Y14 appeared similar to each other. The visual "peak-picking" could identify two EEM peaks: a strong peak around Ex $240 \mathrm{~nm}$ and Em $440 \mathrm{~nm}$ and a weak peak around Ex $275 \mathrm{~nm}$ and Em $330 \mathrm{~nm}$. The weak peak became much stronger in Y10 and W12 WEOM samples, so that the EEM spectra of the two WEOM samples were more similar to each other than to those of Y6 and Y14, highlighted because these fields have drastically different management. In the spectra of Y10 and W12, the excitation wavelength of the humic-like peak up-shifted to 250 to $260 \mathrm{~nm}$. In the meantime, a weak third peak appeared around Ex $320 \mathrm{~nm}$ and Em $430 \mathrm{~nm}$. These observations suggested there were some differences in fluorescence characteristics in these WEOM samples. However, PARAFAC analysis of all 60 EEM spectra revealed the two component model provided the best fit components model. Component 1 was featured with a strong peak at Ex $240 \mathrm{~nm}$ and Em $445 \mathrm{~nm}$, and a shoulder at Ex $320 \mathrm{~nm}$ and $\mathrm{Em} 445 \mathrm{~nm}$. Component 1 represents fulvic-like structure in humic materials [42] [43]. Component 2 was characteristic with maximal Ex $240 \mathrm{~nm}$ and Em $320 \mathrm{~nm}$. Component 2 has been related to a strong UV humic-like fluorophore in natural OM [44] [45]. Whereas PARAFAC analysis frequently reveal 


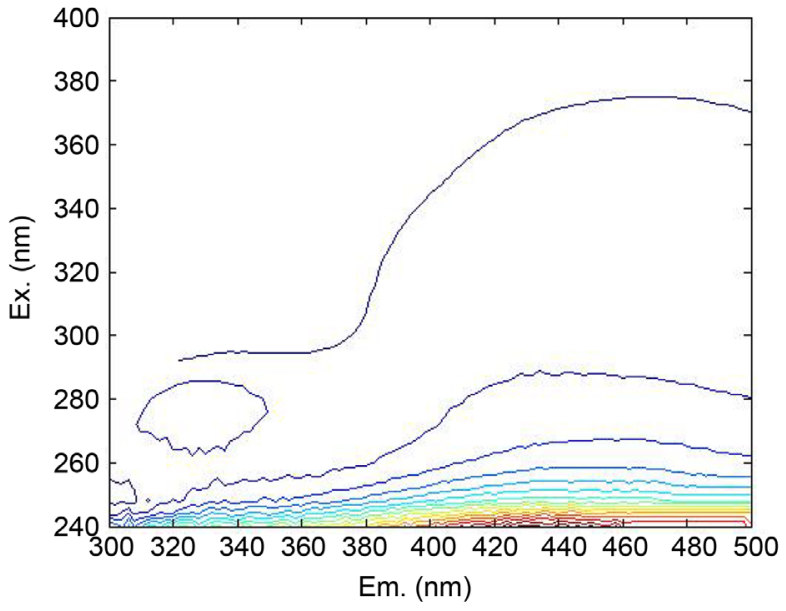

(a) $Y 6$

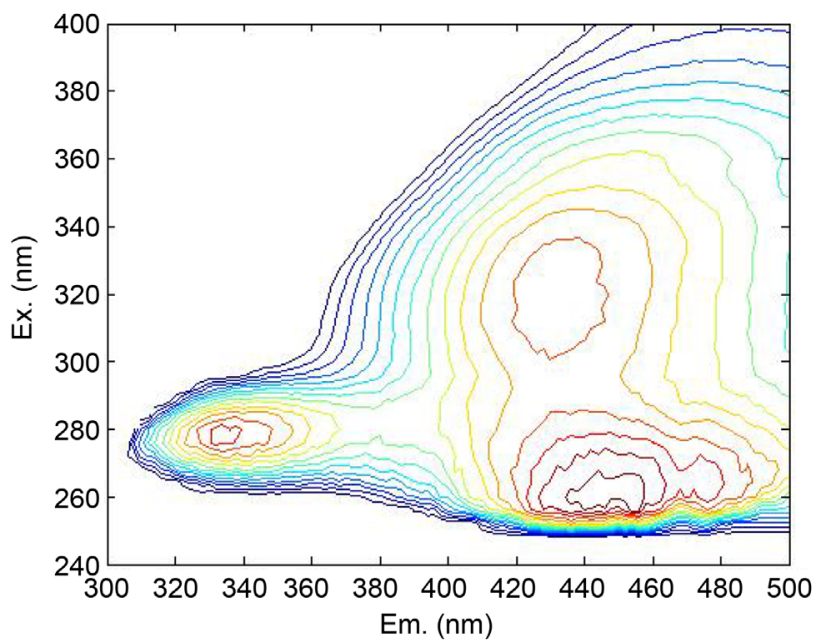

(b) $Y 10$

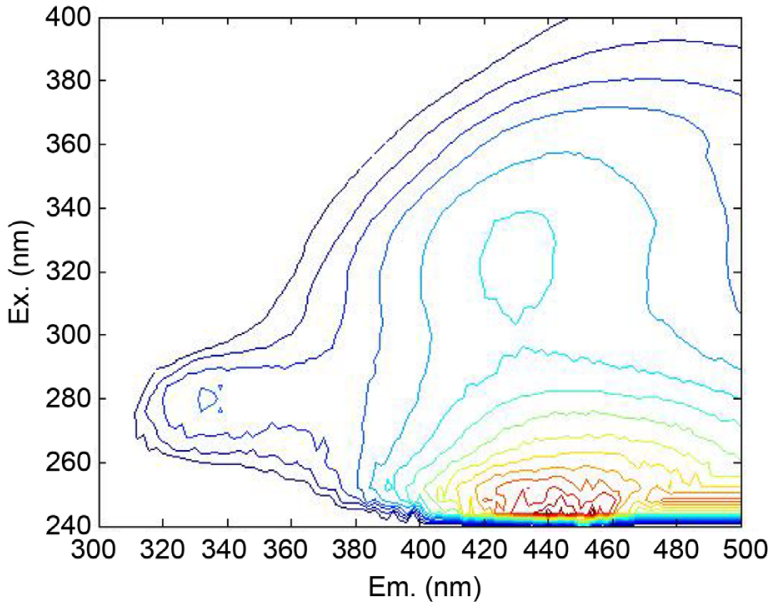

(c) W12

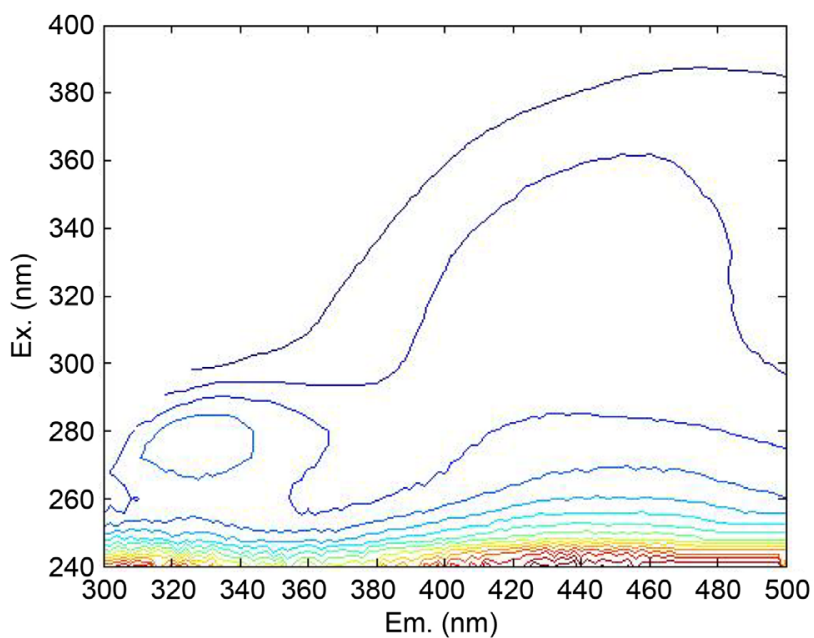

(d) $\mathrm{Y} 14$

Figure 5. Representative fluorescence EEM spectra of water extractable organic matter (WEOM) of Y6, Y10, W12, and Y14 soils collected in 2008, 2004, 2006, and 2002, respectively.

between three and five fluoropheric components [20] [22] [26] [46], the two PARAFAC components suggest the relative simplicity of the WEOM in these Texas soils.

Further analysis of the relative loadings of PARAFAC Components 1 and 2 revealed the impact of the farming management practices (Figure 6). In the synthetic fertilizer fields (Y6 and SW12), humic-like component 2 was greater than fulvic-like component 1. Application of PL increased component 2 in both cultivated and pasture soils. As a result, the relative loading of component 1 was greater than that of component 1 in the WEOM fraction of most of the cultivated soils, with the exception of Y8. As a matter of fact, fulvic-like component has been reported to be a major fluorophoric component in poultry manure [13] [22] [47]. Our observations indicated that PL application was either responsible for direct input of labile fulvic-like OM to soils or stimulated the decomposition of humic-like OM in these soils. 


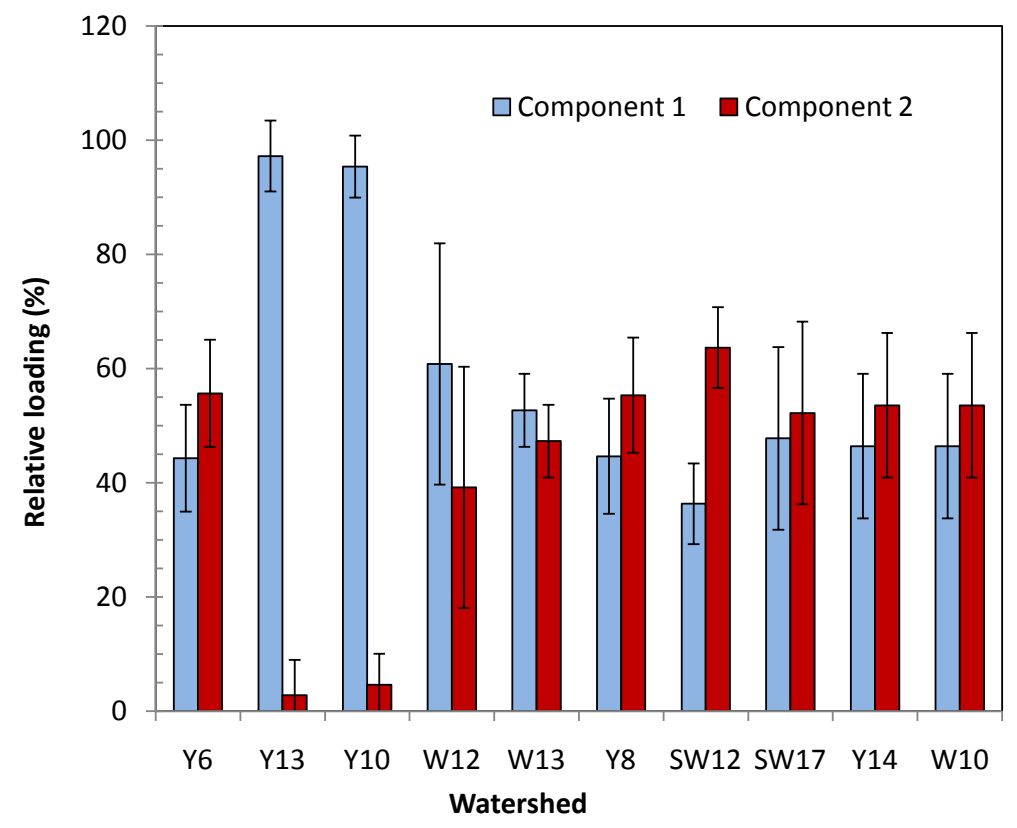

Figure 6. Relative loading of fluorescence component 1 and 2 in the water extractable organic matter (WEOM) fraction from soil samples taken in two-year intervals from 2000 to 2012. The data are average over years, and the standard deviation (error bars) reflects variation of tested parameter over time.

\subsection{Fluorescence Parameters}

Four fluorescence parameters were calculated from the EEM spectral data for further comparison of the impact of management practices on soil WEOM (Figure 7). The FIX values were between 1.09 and 1.19. These values were similar to those obtained from subarctic Alaskan soils with different land uses [20]. It is reported high FIX values $(\sim 1.8)$ indicate WEOM derived from microbes, and low FIX values $(\sim 1.2)$ indicate WEOM from terrestrial origin [21]. Yan et al. [48] reported the FIX values between 1.61 and 1.75 for WEOM in a black soil in Northeastern China. These researchers attributed the observations to mixed plant and microbial precursors for the WEOM. Thus, the quite low FIX values in the current study suggested that the WEOM was mainly plant-originated. On the other hand, the lowest FIX values were observed in the two non-PL applied soils (Y6 and SW12). PL application increased FIX values by $4.2 \%-9.4 \%$ for cultivated soils and $3.6 \%-5.7 \%$ for pasture soils. PL application could have resulted in this small increase in the microbial portion of WEOM.

HIX is another indicator of the degree of decomposition, where higher HIX values suggest more humified WEOM [21]. HIX values vary widely among samples. Sample treatment and storage could also affect the HIX values, but not affect the systematic comparisons between samples [49]. He et al. [50] reported the HIX range from 4 to 16 . Zhao et al. [20] reported the value has a wider range from $>36$ to $<3$. In the current study, the HIX ranged from 1.23 (Y13) to 3.03 (W13), suggesting that very little humification was present in these WEOM samples. Even though the HIX values differed greatly, the impact of management 


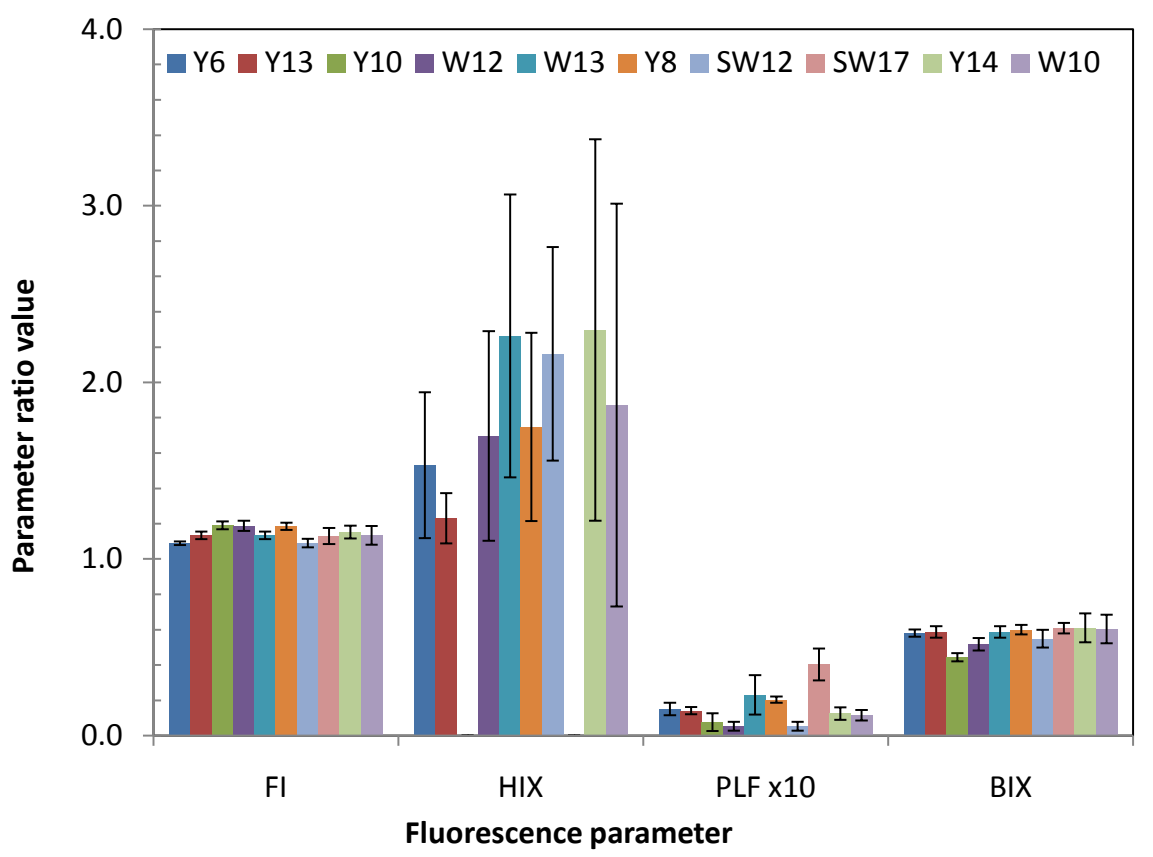

Figure 7. Fluorescence parameters of the water extractable organic matter (WEOM) fraction from soil samples taken from each treatment in two-year interval from 2000 to 2012. FIX, Fluorescence index; HIX, humification index; PLF, polyphenol-like or protein-like fluorescence; BIX, Biological index. The data are average over years, and the standard deviation (error bars) reflects variation of tested parameter over time.

practices was indicated. The high standard deviations suggested that the humification varied year by year. These HIX values clearly indicated that PL application lowered the humified WEOM fractions in these cultivated soils. In contrast, no trend was observed on the degree of humification of WEOM in the pasture soils. It is reported that cropping rotation and compost application greatly lower the HIX values in WEOM samples from potato soils [12] [31].

Whereas HIX is a useful indicator for the WEOM quality, Cuss et al. [23] [51] cautioned that large amounts of proteins and polyphenols may interfere the accuracy of HIX values as the fluorescence of protein- and polyphenol-like components was close to the lower region of HIX (i.e., Em $300-345 \mathrm{~nm}$ ). In other words, a decrease in protein- and polyphenol-like components (i.e., PLF) alone would result in decreasing the lower region of HIX with increasing the HIX value, which may be mistakenly interpreted as increasing humification or aromaticity. Thus, we also calculated PLF and found the values very low $(<0.04)$ (Figure 7). This observation was consistent with very low WEON levels in these WEOM samples (Figure 2). The lower PLF values suggested the interference of PLF on HIX was minimal.

BIX is referred as an indicator of the presence of autochthonous biological activity [23] [34], BIX has also been called a "freshness indicator" [18]. A high BIX $(>1)$ is attributed to a predominantly autochthonous origin of WEOM and to the presence of OM freshly released into water, whereas a low BIX indicates lower autochthonous WEOM production. In addition, decomposition of the autoch- 
thonous OM components led to a marked decrease of BIX, followed by the production of new humic-like fluorescence peaks. The BIX values in these soil samples were around 0.6 , similar to those in potato rotation soils (between 0.5 - 0.6) [31] and in organic farming and agroforestry soils (around 0.76) [18]. This observation suggested that the WEOM pool in these soil samples were contributed mainly from decomposed plant residues and little WEOM was derived from the fresh active crop root and indigenous microbial exudates. The impact of PL application on the BIX values was not clear and consistent, probably reflecting the high degree of dynamics of the fresh WEOM input from poultry litter.

\section{Conclusion}

Positive relationships existed with $\mathrm{PL}$ application rate and soil $\mathrm{NO}_{3}-\mathrm{N}$ and soil WEOC concentrations. A sharp increase in soil WEON was observed when PL

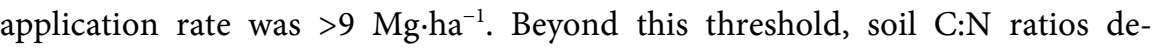
creased, indicating the accumulation of organic $\mathrm{N}$ in soil that was not used by growing crops. Grazing management lowered soil WEON. Analysis of UV-Vis and fluorescence spectral properties indicated that the WEOM from these soils were mainly composed of humic- and fulvic-like components and contributed from old plant residues. PL application increased the proportion of decomposable fulvic-like OM in the cultivated soils. However, a similar increase was not observed in pasture soils where the content of humic-like portion was still greater than that of fulvic-like portions in the PL-applied pasture soils.

\section{Acknowledgements}

The research is partially funded by USDA Hatch project through Alaska Fairbanks Experiment Farm. Mention of trade names or commercial products in this publication is solely for the purpose of providing specific information and does not imply recommendation or endorsement by the US Department of Agriculture. USDA is an equal opportunity provider and employer.

\section{References}

[1] He, Z., Ed. (2012) Applied Research of Animal Manure: Challenges and Opportunities beyond the Adverse Environmental Concerns. Nova Science Publishers, New York.

[2] He, Z., Ed. (2011) Environmental Chemistry of Animal Manure. Nova Science Publishers, NY.

[3] He, Z., Pagliari, P.H. and Waldrip, H.M. (2016) Applied and Environmental Chemistry of Animal Manure: A Review. Pedosphere, 26, 779-816. https://doi.org/10.1016/S1002-0160(15)60087-X

[4] He, Z., Honeycutt, C.W., Tazisong, I.A., Senwo, Z.N. and Zhang, D. (2009) Nitrogen and Phosphorus Accumulation in Pasture Soil from Repeated Poultry Litter Application. Communications in Soil Science and Plant Analysis, 40, 587-598. https://doi.org/10.1080/00103620902861971

[5] Tewolde, H. and Sistani, K. (2014) Cotton Production Improvement and Environmental Concerns from Poultry Litter Application in Southern and Southeastern 
USA Soils. In: He, Z. and Zhang, H., Eds., Applied Manure and Nutrient Chemistry for Sustainable Agriculture and Environment, Amsterdam, 355-370. https://doi.org/10.1007/978-94-017-8807-6_17

[6] Tewolde, H., Shankle, M.W., Way, T.R., Adeli, A., Brooks, J.P. and He, Z. (2015) Enhancing Management of Fall-Applied Poultry Litter with Cover Crop and Subsurface Band Placement in No-Till Cotton. Agronomy Journal, 107, 449-458. https://doi.org/10.2134/agronj14.0266

[7] Harmel, R.D., Smith, D.R., Haney, R.L. and Dozier, M. (2009) Nitrogen and Phosphorus Runoff from Cropland and Pasture Fields Fertilized with Poultry Litter. Journal of Soil and Water Conservation, 64, 400-412. https://doi.org/10.2489/jswc.64.6.400

[8] Waldrip-Dail, H., He, Z., Erich, M.S. and Honeycutt, C.W. (2009) Soil Phosphorus Dynamics in Response to Poultry Manure Amendment. Soil Science, 174, 195-201. https://doi.org/10.1097/SS.0b013e31819cd25d

[9] Waldrip, H.M., Pagliari, P.H., He, Z., Harmel, R.D., Cole, N.A. and Zhang, M. (2015) Legacy Phosphorus in Calcareous Soils: Effects of Long-Term Poultry Litter Application. Soil Science Society of America Journal, 79, 1601-1614.

https://doi.org/10.2136/sssaj2015.03.0090

[10] Zhang, M., He, Z., Zhao, A., Zhang, H., Endale, D.M. and Schomberg, H.H. (2011) Water-Extractable Soil Organic Carbon and Nitrogen Affected by Tillage and Manure Application. Soil Science, 176, 307-312.

https://doi.org/10.1097/SS.0b013e31821d6d63

[11] Zhang, M., He, Z. and Zhao, A. (2011) Ultraviolet-Visible Absorptive Features of Water Extractable and Humic Fractions of Animal Manure and Relevant Compost. In. He, Z., Ed., Environmental Chemistry of Animal Manure, Nova Science Publishers, NY, 61-81.

[12] Zhang, M., He, Z. and Zhao, A. (2015) Water-Extractable Organic Carbon and Nitrogen Affected by Crop Rotation and Fertilizer Management. In: He, Z. and Wu, F., Eds., Labile Organic Matter-Chemical Compositions, Function, and Significance in Soil and the Environment, SSSA Special Publication 62, Madison, 119-136. https://doi.org/10.2136/sssaspecpub62.2014.0038

[13] Singh, S., Dutta, S. and Inamdar, S. (2014) Land Application of Poultry Manure and Its Influence on Spectrofluorometric Characteristics of Dissolved Organic Matter. Agriculture, Ecosystems \& Environment, 193, 25-36.

[14] Wang, G. and Zhou, L. (2017) Application of Green Manure and Pig Manure to Cd-Contaminated Paddy Soil Increases the Risk of Cd Uptake by Rice and Cd Downward Migration into Groundwater: Field Micro-Plot Trials. Water, Air, \& Soil Pollution, 228, 29. https://doi.org/10.1007/s11270-016-3207-2

[15] He, Z. and Wu, F. (2015) Labile Organic Matter: Chemical Compositions, Function, and Significance in Soil and the Environment. SSSA Special Publication 62, Wisconsin, Soil Science Society of America, Madison.

[16] Jaffrain, J., Gerard, F., Meyer, M. and Ranger, J. (2007) Assessing the Quality of Dissolved Organic Matter in Forest Soils using Ultraviolet Absorption Spectrophotometry. Soil Science Society of America Journal, 71, 1851-1858. https://doi.org/10.2136/sssaj2006.0202

[17] Ohno, T., He, Z., Tazisong, I.A. and Senwo, Z.N. (2009) Influence of Tillage, Cropping, and Nitrogen Source on the Chemical Characteristics of Humic Acid, Fulvic Acid, and Water-Soluble Soil Organic Matter Fractions of a Long-Term Cropping System Study. Soil Science, 174, 652-660. 
https://doi.org/10.1097/SS.0b013e3181c30808

[18] Sun, H.Y., Koal, P., Gerl, G., Schroll, R., Joergensen, R.G. and Munch, J.C. (2017) Response of Water Extractable Organic Matter and Its Fluorescence Fractions to Organic Farming and Tree Species in Poplar and Robinia-Based Alley Cropping Agroforestry Systems. Geoderma, 290, 83-90.

[19] Wilson, H.F. and Xenopoulos, M.A. (2009) Effects of Agricultural Land Sue on the Composition of Fluvial Dissolved Organic Carbon. Nature Geoscience, 2, 37-41. https://doi.org/10.1038/ngeo391

[20] Zhao, A., Zhang, M. and He, Z. (2013) Spectroscopic Characteristics and Biodegradability of Cold and Hot Water Extractable Soil Organic Matter under Different Land Uses in Subarctic Alaska. Communications in Soil Science and Plant Analysis, 44, 3030-3048. https://doi.org/10.1080/00103624.2013.829086

[21] Zhang, M. and He, Z. (2015) Characteristics of Dissolved Organic Carbon Revealed by Ultraviolet-Visible Absorbance and Fluorescence Spectroscopy: The Current Status and Future Exploration. In: He, Z. and Wu, F., Eds., Labile Organic Matter-Chemical Compositions, Function, and Significance in Soil and the Environment, SSSA Special Publication 62, Madison, 1-22. https://doi.org/10.2136/sssaspecpub62.2014.0032

[22] Ohno, T. and He, Z. (2011) Fluorescence Spectroscopic Analysis of Organic Matter Fractions: The Current Status and a Tutorial Case Study. In: He, Z., Ed., Environmental Chemistry of Animal Manure, Nova Science Publishers, NY, 83-103.

[23] Cuss, C.W. and Gueguen, C. (2015) Characterizing the Labile Fraction of Dissolved Organic Matter in Leaf Leachates: Methods, Indicators, Structure, and Complexity. In: He, Z. and Wu, F., Eds., Labile Organic Matter-Chemical Compositions, Function, and Significance in Soil and the Environment, Madison, 237-274. https://doi.org/10.2136/sssaspecpub62.2014.0043

[24] Waldrip, H.M., He, Z., Todd, R.W., Hunt, J.F., Rhoades, M.B. and Cole, N.A. (2014) Characterization of Organic Matter in Beef Feedyard Manure by Ultraviolet-Visible and Fourier Transform Infrared Spectroscopies. Journal of Environmental Quality, 43, 690-700. https://doi.org/10.2134/jeq2013.09.0358

[25] Mouloubou, O.R., Prudent, P., Mounier, S., Boudenne, J.-L., Abaker, M.G. and Theraulaz, F. (2016) An Adapted Sequential Chemical Fractionation Coupled with UV and Fluorescence Spectroscopy for Calcareous Soil Organic Matter Study after Compost Amendment. Microchemical Journal, 124, 139-148.

[26] Zeng, Z., Zheng, P. and Ding, A. (2017) Source Analysis of Organic Matter in Swine Wastewater after Anaerobic Digestion with EEM-PARAFAC. Environmental Science and Pollution Research, 24, 6770-6778. https://doi.org/10.1007/s11356-016-8324-3

[27] Harmel, R.D., Haney, R.L. and Smith, D.R. (2011) Effects of Annual Turkey Litter Application on Surface Soil Quality of a Texas Blackland Vertisol. Soil Science, 176, 227-236.

[28] Haney, R.L., Franzluebbers, A.J., Jin, V.L., Johnson, M.-V., Haney, E.B., White, M.J. and Harmel, R.D. (2012) Soil Organic C:N vs. Water-Extractable Organic C:N. Open Journal of Soil Science, 2, 269-274. https://doi.org/10.4236/ojss.2012.23032

[29] Petersen, R.G. and Calvin, L.D. (1996) Sampling. In: Sparks, D.L., Ed., Methods of soil Analysis, Part 3, Chemical Methods, Madison, 1-18.

[30] Zhao, A., Zhang, M. and He, Z. (2012) Characteristics of Soil Water-Soluble Organic C and N under Different Land Uses in Alaska. Soil Science, 177, 683-694. https://doi.org/10.1097/SS.0b013e31827e1fa8 
[31] He, Z., Zhang, M., Zhao, A., Olanya, O.M., Larkin, R.P. and Honeycutt, C.W. (2016) Quantity and Nature of Water-Extractable Organic Matter from Sandy Loam Soils with Potato Cropping Management. Agricultural and Environmental Letters, 1, Article ID: 160023. https://doi.org/10.2134/ael2016.06.0023

[32] He, Z., Honeycutt, C.W. and Griffin, T.S. (2003) Comparative Investigation of Sequentially Extracted P Fractions in a Sandy Loam Soil and a Swine Manure. Communications in Soil Science and Plant Analysis, 34, 1729-1742. https://doi.org/10.1081/CSS-120021308

[33] He, Z., Mao, J., Honeycutt, C.W., Ohno, T., Hunt, J.F. and Cade-Menun, B.J. (2009) Characterization of Plant-Derived Water Extractable Organic Matter by Multiple Spectroscopic Techniques. Biology and Fertility of Soils, 45, 609-616. https://doi.org/10.1007/s00374-009-0369-8

[34] Zhang, Y., Liu, X., Wang, M. and Qin, B. (2013) Compositional Differences of Chromophoric Dissolved Organic Matter Derived from Phytoplankton and Macrophytes. Organic Geochemistry, 55, 26-37.

[35] Weishaar, J.L., Aiken, G.R., Bergamaschi, B.A., Fram, M.S., Fujii, R. and Mopper, K. (2003) Evaluation of Specific Ultraviolet Absorbance as an Indicator of the Chemical Composition and Reactivity of Dissolved Organic Carbon. Environmental Science and Technology, 37, 4702-4708. https://doi.org/10.1021/es030360x

[36] Hassouna, M., Théraulaz, F. and Massiani, C. (2012) Production and Elimination of Water Extractable Organic Matter in a Calcareous Soil as Assessed by UV/Vis Absorption and Fluorescence Spectroscopy of Its Fractions Isolated on XAD-8/4 Resins. Geoderma, 189-190, 404-414.

[37] De Troyer, I., Amery, F., Van Moorleghem, C., Smolders, E. and Merckx, R. (2011) Tracing the Source and Fate of Dissolved Organic Matter in Soil after Incorporation of a ${ }^{13} \mathrm{C}$ Labelled Residue: A Batch Incubation Study. Soil Biology and Biochemistry, 43, 513-519.

[38] Hunt, J.F., Ohno, T., He, Z., Honeycutt, C.W. and Dail, D.B. (2007) Influence of Decomposition on Chemical Properties of Plant- and Manure-Derived Dissolved Organic Matter and Sorption to Goethite. Journal of Environmental Quality, 36, 135-143. https://doi.org/10.2134/jeq2006.0133

[39] Sellami, F., Hachicha, S., Chtourou, M., Medhioub, K. and Ammar, E. (2008) Maturity Assessment of Composted Olive Mill Wastes using UV Spectra and Humification Parameters. Bioresource Technology, 99, 6900-6907.

[40] Osborne, T.Z., Inglett, P.W. and Reddy, K.R. (2007) The Use of Senescent Plant Biomass to Investigate Relationships between Potenital Particulate and Dissolved Organic Matter in a Wetland Ecosystem. Aquatic Botany, 86, 53-61.

[41] Silveira, M.L., Reddy, K.R. and Comeford, N.B. (2011) Litter Decompostion and Soluble Carbon, Nitrogen, and Phosphorus Release in a Forest Ecosystem. Open Journal of Soil Science, 1, 86-96. https://doi.org/10.4236/ojss.2011.13012

[42] He, Z., Ohno, T., Cade-Menun, B.J., Erich, M.S. and Honeycutt, C.W. (2006) Spectral and Chemical Characterization of Phosphates Associated with Humic Substances. Soil Science Society of America Journal, 70, 1741-1751. https://doi.org/10.2136/sssaj2006.0030

[43] Santin, C., Yamashita, Y., Otero, X.L., Alvarez, M.A. and Jaffe, R. (2009) Characterizing Humic Substances from Estuarine Soils and Sediments by Excitation-Emission Matrix Spectroscopy and Parallel Factor Analysis. Biogeochemistry, 96, 131-147. https://doi.org/10.1007/s10533-009-9349-1

[44] He, Z., Ohno, T., Wu, F.C., Olk, D.C., Honeycutt, C.W. and Olanya, M. (2008) Ca- 
pillary Electrophoresis and Fluorescence Excitation-Emission Matrix Spectroscopy for Characterization of Humic Substances. Soil Science Society of America Journal, 72, 1248-1255. https://doi.org/10.2136/sssaj2007.0305

[45] He, Z., Ohno, T., Olk, D.C. and Wu, F. (2010) Capillary Electrophoresis Profiles and Fluorophore Components of Humic Acids in Nebraska Corn and Philippine Rice Soils. Geoderma, 156, 143-151.

[46] Jamieson, T., Sager, E. and Gueguen, C. (2014) Characterization of Biochar-Derived Dissolved Organic Matter using UV-Visible Absorption and Excitation-Emission Fluorescence Spectroscopies. Chemosphere, 103, 197-204.

[47] Hunt, J.F. and He, Z. (2015) Characteristics of Plant-Derived Water-Extractable Organic Matter and Its Effects on Phosphorus Sorption Behavior. In: He, Z. and Wu, F., Eds., Labile Organic Matter-Chemical Compositions, Function, and Significance in Soil and the Environment, SSSA Spec. Publ. 62, Madison, 99-118. https://doi.org/10.2136/sssaspecpub62.2014.0037

[48] Yan, L., Zhang, J., Zhao, X., Li, M., Gao, Q. and Zhao, L. (2016) Effect of Long-Term Application of Corn Stalks and Inorganic Fertilizers on Fluorescence Characteristics of Water Extractable Organic Matter in a Meadow Black Soil of Northeast China. Toxicological and Environmental Chemistry, 98, 541-550. https://doi.org/10.1080/02772248.2015.1133372

[49] Sun, S.-Q., Cai, H.-Y., Chang, S.X. and Bhatti, J.S. (2015) Sample Storage-Induced Changes in the Quantity and Quality of Soil Labile Organic Carbon. Scientific Reports, 5, Article No. 17496. https://doi.org/10.1038/srep17496

[50] He, X.-S., Xi, B.-D., Li, X., Pan, H.-W., An, D., Bai, S.-G., Li, D. and Cui, D.-Y. (2013) Fluorescence Excitation-Emission Matrix Spectra Coupled with Parallel Factor and Regional Integration Analysis to Characterize Organic Matter Humification. Chemosphere, 93, 2208-2215.

[51] Cuss, C.W. and Gueguen, C. (2013) Distinguishing Dissolved Organic Matter at Its Origin: Size and Optical Properties o Leaf-Litter Leachates. Chemosphere, 92, 1483-1489.

[52] Desalegn, G., Binner, E. and Lechner, P. (2008) Humification and Degradability Evaluation during Composting of Horse Manure and Biowaste. Compost Science and Utilization, 16, 90-98. https://doi.org/10.1080/1065657X.2008.10702363

[53] Kang, S. and Xing, B. (2008) Humic Acid Fractionation upon Sequential Adsorption onto Goethite. Langmuir, 24, 2525-2531. https://doi.org/10.1021/la702914q 